\section{CHINESE LANGUAGE TEACHING IN THAILAND}

\section{Prapin Manomaiviboon ${ }^{1}$}

\begin{abstract}
This article is about the present day teaching and learning of Chinese in Thailand, particularly over the past seven to eight years. However, before dealing with the state of current teaching and learning, this article will present a concise historical version of Chinese language education in Thailand, so that readers will get a perspective and will be aware of diverse factors affecting Chinese teaching in the country.
\end{abstract}

\section{History of Chinese language teaching in Thailand}

According to the archives of the Department of Special Schools Division, Ministry of Education, concerning Chineselanguage private schools, the first Chineselanguage school in Thailand was founded on an island in Ayutthya Province in 1782. Later this school came to be known as "Ko Rian" (Class Island). Chinese was the school's single course offering, with an enrollment of about 200 pupils. No evidence exists as to the identity of the school founder. Since there was no government supervision of schools at that time, it is not possible to ascertain when the school ceased operation.

${ }^{1}$ Ph.D., Associate Professor, and Director of Asia Research Centor, Chulalongkorn University.
Afterwards, an American missionary group led by Mrs. Mathoon founded a Chinese-language boarding school near Wat Aroon Rajavararam (the Temple of Dawn), Thonburi. The establishment opened on 30 September 1852, with Mr. Kieng Kwa Sib, a teacher among the missionary group on charge of teaching functions. According to the archives of the Special Schools Division, Ministry of Education, the school initially had 27 male pupils. Later it grew larger in size and admitted girls too. Unfortunately, Mr. Kieng Kwa Sib passed away in 1860. The teacher who took over the running of the courses was a Thai and, understandably, adopted Thai as the medium of instruction in all subjects. The change in the medium of instruction spelt the end of Chinese-language schools at that time. Indeed, the establishment of Chinese-language schools was in abeyance for quite a long time after that. Then in 1908, the Zhonghua Huiguan Association established the Chineselanguage school Hua Yi in Captain Bush Lane, off New Road, Bangkok. Three teachers arrived from China to make up the entire teaching staff. The school was of immense benefit to children of the diasporic Chinese community. However, the school shut down before long since the teachers and the operators were preoccupied with the issue of revolution in China and had little time for instructional work.

Shortly afterwards, a consortium of Expatriate Chinese Associations, namely the Chaozhou Association, the Hainan Association, the Guangdong Association, the Hakka Association, and the Fujian Association founded the Chinese-language school Xin Min. Since most of the school administrators were of Chaozhou descent, the language of instruction was 
Chaozhou. Understandably, later the other ethnic communities decided to break up the partnership so as to found a school each, where their own particular variant was the language of instruction. The first group to withdraw was the Hakka Association, who founded Jin De School in 1915. The other groups followed suit. The Guangdong Association founded Ming De School in 1914. The Fujian Association set up Pei Yuan School in 1915. The Hainan Association established Yu Min School in 1921 (Coughlin 1960: 146). Thus, the several expatriate Chinese Associations played a very significant role in the expansion of Chineselanguage schools in Thailand at the outset.

Apart form state-authorized schools, during the same period, private Chineselanguage schools run by educationminded Chinese expatriates were springing up in districts settled by the diasporic Chinese communities far and wide. For example, the Chinese of Guangdong descent set up the first Chinese-language girls' school called Kun De School in 1917. During the 1920 s the number of Chinese-language schools grew very rapidly. In 1920, there were only about 30 Chinese-language primary schools. The year 1932, however, saw a total of over 200 Chinese-language primary and secondary schools all told (Coughlin 1960: 146-147)

The dramatic increase in the number of Chinese-language schools early in the twentieth century can be traced to the following factors: the Chinese pride in their own culture; patriotism, expansion of Chinese $\mathrm{c}$ ommunities with ever-renewing flow of new immigrants; expansion of mercantile Chinese communities, competition with European expatriates in Thailand both on commercial and educational fronts (more schools having been opened by European missionaries), and floods of highly literate Chinese fleeing from political turmoil and dire economic conditions in their country who arrived in Thailand after 1920 (Coughlin 1960: 147). Besides, at that time the authorities were still lax with the government of the school system. So the practice of founding Chineselanguage schools was widespread.

Nevertheless, following the change from absolute to constitutional monarchy in 1932, the incumbent Thai government sought to divert the loyalty that Thai people had felt exclusively to the King to loyalty to the nation instead. Thus, the Chinese language schools which placed a much greater emphasis on the teaching of Chinese than on Thai flew in the face of government policy at that time. The year 1933 saw the passing of a statute limiting the class sessions of Chinese along with other foreign language in all schools to a possible maximum of 6 hours a week out of the total number of 28 sessions a week. Any school violating this law would be closed. In fact, seventy-nine Chinese-language schools defying the regulation were forced by the national government to close down between 1933 and 1935 (Coughing 1960: 146)

On 7 July 1938 a dispute broke out between China and Japan at Lugou Siao Bridge, leading later to war between the two countries. Throughout the SinoJapariese war, the expatriate Chinese the community in Thailand; a long with Chinese-language schools and Chinese teachers, raised funds and sent the money to China to help defray war-related expenses. Secret societies involved in antiJapanese activities and in boycotting 
Japanese imports were founded. The Thai government at that time became an ally to the Japanese during World War II (1939-1945). Wary of the ways in which Chinese activities in Thailand might hurt Thai-Japanese relations, the government forbade the Chinese to raise money and placed heavy restrictions on the Chinese language press. In addition, the Minister of Education in 1939 ordered Chineselanguage schools to teach Chinese for only two hours a week, with the remainder of the class schedule devoted to Thai-language lessons. Any schools which violated the rule would have to be closed. According to the Ministry of Education's records, in 1939 Chineselanguage private schools across the country numbered 294. Fifty-one among these schools ceased operation of their own accord. The rest were closed by the Ministry of Education until there were only two left in 1951 (Chokkajitsumpun 1998: 59). The control of Chinese language schools during the second World War period went down in history as the time when Thai authorities imposed the strictest ever restrictions over educational institutions.

When World War II was over, China belonged to the victorious side, while Thailand's status was somewhat dubious. Although not exactly lumped into the defeated camp, the country faltered, having allied itself with Japan in the Second World War. As a result the Chinese expatriates in Thailand exulted in the victory of their mother country and mistakenly believed that they no longer needed to be under Thai law. All the Chinese-language schools which had been closed by the Thai authorities during World War II revived. Also, new Chinese-language schools both in the nation's capital and in the provinces were founded. Towards the close of 1949 , there were about 450 Chinese language schools all told (Chokkajitsumpun 1998: 59).

After the inauguration of the Chinese Embassy in Bangkok on 17 September 1946, high-level negotiations took place concerning Chinese-language schools initiated by the Chinese in Thailand. A settlement was reached in May 1947, to the effect that the government would adopt a lenient stance, permitting Chinese-language schools to teach Chinese for 10 hours a week out of the overall class session of 30 hours a week

However, China's political upheaval in 1949 spurred on more extensive operations on the part of the long-standing Chinese Communist Party in Thailand. The party members furtively used the buildings on school premises and the facilities (=buildings) of other Chinese owned institutions as base of operations. Consequently, the government once more implemented firm control of Chineslanguage school. A large number of schools went out of business and many more were closed by the authorities, so that the number of Chinese-language schools was down to 177 in 1959 (Sachakul 1984: 6). Between 1960 and 1988 the Thai government inspected Chinese-language schools on a regular basis. Permission was granted to Chinese-owned schools for teaching Chinese only at primary level, with Chinese-language class sessions numbering 5 hours a week out of a possible weekly total of 30 hours. In addition, the Ministry of Education adopted the policy of freezing the number of Chineselanguage schools. Hence there were only 120 Chinese-language schools in 1988 (Chokkajitsumpun 1998: 63) 
In January 1989, the Sino-Thai Chamber of Commerce, the Chaozhou Association, and people who were aware of the important status of Chinese joined forces to petition the Ministry of Education for an extension in Chinese language teaching beyond the Prathom One to Prathom Four levels. In May 1989, permission was officially granted for offering Mandarin from the kindergarten years through primary school (Prathom 6) as an additional foreign language option apart form English. Then in February 1992, the authorities fully established Mandarin on the same basis as all the other foreign languages (English, French, German and Japanese) traditionally taught in Thai schools. Moreover, permission was granted for enlisting the services of native speakers of Chinese from the People's Republic of China as teachers of the language, provided that they hold a bachelor's degree or graduate from colleges of education. Meanwhile, the Ministry of Education focused on development of French German, Japanese, and Chinese language courses for students in senior high schools. Schools began to follow these language syllabi in 1997 (Chokkajitsumpun 1998: 67-68). Since then the Ministry of Education has sought to promote the teaching and learning of Chinese.

\section{Current state of Chinese language education}

The study of Chinese in Thailand has gained in popularity since 1992. At present, Chinese draws the largest number of learners next to English. This dramatic surge in popularity probably results from the following factors:
1. In the wake of the Thai financial crisis, companies have resorted to numerous layoffs. However, employees with knowledge of Chinese have survived unscathed and have continued to thrive. It is now clear that today Chinese plays a prominent role in Thailand commercially and economically. Joint Sino-Thai investment in various areas of business has risen sharply. As a result, Chinese has become essential in bilateral trade relations.

2. A number of Chinese high-ranking dignitaries have visited Thailand. Her Majesty the Queen has been to China on a state visit. Besides, Her Royal Highness Princess Sirindhorn's Chinese language study visit to Beijing University from February to March 2001 was widely covered on Thai television on a daily basis. The news broadcast has served to inspire an even greater interest in Chinese language teaching and learning among Thai people.

3. Since 1998 Chinese has been another foreign language option available to Thai schoolleavers on sitting university entrance examinations. Students planning to satisfy entrance requirements of undergraduate programs in the humanities and the social sciences can opt for a Chinese language paper instead of French or German papers. Such flexibility accounts for Chinese becoming a more popular choice.

4. Chinese joined the WTO in 2001. As everyone knows, China is hosting the Olympic Game in 2008. Besides, the year 2010 will see Shanghai playing host to the World Expo.

5. Thailand and China initiated an agricultural produce Free Trade Area in October, 2003. 


\section{Teaching and learning Mandarin at primary and secondary levels}

Nowadays Mandarin is taught at both primary and secondary levels. In Bangkok there about 100 state schools offering Chinese as a foreign language other than English. Of these, over fifty are schools under the supervision of the Department of General Education, and over forty are under the control of BMA (Bangkok Metropolitan Area). In addition, there are 118 Chinese-language private schools, most of which have been in operation since well before 1988. According to the survey carried out in 2003, these schools are located in Bangkok and in 51 other provinces (see Table No.1 in the Appendix) Of all the Chinese-language schools mentioned in Table No.1, only 12 provide secondary education (see Table No.2 in the Appendix)

Among Chinese-language secondary schools, Patrapakdi School is the most recent establishment. The school was founded by the Thailand Chapter of the Chaozhou Association in response to the policy set by His Excellency the Prime Minister, Lieutenant Colonel Dr.Taksin Shinawat, who, on his visit to China, had assured Chairman, Jing Zemin of the People's Republic of China of the Thai government's commitment to embracing the academic subject of Mandarin in secondary schools all over Thailand. The Chaozhou Association went ahead with the construction of the school in 2002. During the preparation period, the school collaborated with the faculty of Beijing University on educational management and on syllabus development. Construction was completed in 2003 and the establishment was named "Patrapakdi School." The school admits students to
Matayom Suksa 1 through Matayom Suksa 6, who study Chinese for 2 sessions a day, that is to say, 10 hours a week, as is common practice in Chineselanguage schools generally. Patrapakdi School has been in operation since the first semester of the academic year 2003 .

\section{Teaching and learning Mandarin at tertiary level}

Before the 1970s the academic subject of Mandarin was not offered at university. It is Chulalongkorn University, the oldest Thai university, which innovated, and where preparations for offering Chinese as a major were first set in motion. This current academic year 2004 sees a total of 32 state and private universities across Thailand offering Chinese at undergraduate level, of which 10 offer Chinese as a major program (see Table No.3 in the Appendix)

Chulalongkorn University is the first and only Thai university to offer a graduate (Master's degree) program in Chinese. The M.A. program in Chinese was inaugurated in 1996, with the first crop of graduate students arriving in 1997. This program receives significant support from the Department of Chinese at Beijing University. Visiting faculty members from Beijing University teach at Chula each semester in line with the academic co-operation agreement between Beijing and Chulalongkorn Universities. All graduate students are required to spend two months on research leading up to their thesis at Beijing University. The Chinese partner university will be responsible for assigning faculty advisors who will supervise the students' work during their residence in Beijing. Hence, it can be said that the Master's program in Chinese at Chula is thriving, thanks to 
the support of the Department of Chinese, Beijing University. To date the Chula degree program has produced program has produced 22 graduates. It is expected that another 6 will complete their studies this academic year or the next.

At present the supply of Chinese language teachers in Thailand is woefully inadequate. As a result, Chulalongkorn University's F aculty of A rts has s ought to forge collaborative links with educational institution in China and Taiwan which offer graduate programs in Teaching Chinese as a Foreign Language. The aim is to produce graduates who specialize in TCFL and who are qualified to teach Chinese as an academic subject at $v$ arious e ducational institutions. After some two years of liaison arrangements and preparations, an international Master of Arts Program in Chinese as a Foreign Language was inaugurated at the outset of the academic year 2004. The training of the first batch of students has been facilitated by a cooperation agreement with National Taiwan Normal University, under the terms of which the Taiwanese partner university sends its faculty members to help with the teaching of three courses throughout the first and second semesters. Chula student must spend their third semester at NTNU taking three courses. The international program involves the use of Chinese and English as the languages of instruction throughout. A Master's thesis is compulsory as a major component of the program.

In addition to Chinese language courses available from primary to secondary to tertiary levels as detailed above, Chinese language centers proliferate all over the country. Bangkok alone has over 90 Chinese language centers sponsored and run by the private sector. These Chinese language centers open every day, both in the daylight and evening hours. The language programs available include a series of language courses from beginners to advanced levels as well as lessons custom-tailored to individual requirements. Besides the numerous Chinese language centers, several universities offer Chinese language courses as part of community education, serving the public outside the campus. They conduct Chinese language classes in the evenings and at weekends, so that people wishing to learn Chinese but who are workplace-based 5 days a week can now sign up for Chinese courses. In 1982, the Faculty of Arts at Chulalongkorn University became the first state institution to hold evening programs in Chinese for the general public and has continued to do so up to now, with 350 people on average attending per year. The programs on offer range from elementary courses for absolute beginners to classes designed for students with some prior knowledge of Chinese who wish to improve their skills. Generally speaking, such courses are conducted by faculty members from the Chinese Department / Division affiliated to the relevant university. However, the academic structure at Mae $\mathrm{Fa}$ Luang University is unique among higher education institutions. In other words, Mae Fa Luang University is privileged to have the Sirindhorn Language and Cultural Center as the unit responsible for offering Chinese language classes to the community outside the university campus.

In addition, another innovation in Chinese language education is distance learning via satellite television. Currently the only school which conducts teaching in this way is Klaikungwol School in 
Hua Hin District, Prachuab Khiri K han Province. Also, in 2004 Sukhothai Dhammadhiraj University, an open university as well as a distance learning institution, completed a series of textbooks on Chinese for Communication: Foundation Course I. Preparations are now under way for teaching the course by distance learning method via television and radio broadcasts. Also, online Chinese courses have become available. In 2003 the continuing Education Center at Chulalongkorn University for the first time innovated and experimented with teaching Chinese through the internet.

\section{Problems connected with present- day Chinese language teaching and learning}

It is clear that Chinese courses are at present enormously popular in Thailand, with support from government agencies and the private sector alike. Even so, a number of problems have plagued Chinese language learning and teaching:

1. Currently all the six Chinese language newspapers published in Thailand are printed in old-style script, using traditional Chinese characters. However, knowledge of a single form of script is far from adequate. At present Thailand is the economic powerhouse of Southeast Asia and belongs to a free trade zone. The country is active in maintaining strong ties and commercial links with the People's Republic of China, Taiwan, and Hong Kong. Since Chinese is virtually the lingua franca with regard to international trading links in this region, it has become necessary to learn both writing systems, namely both the traditional and simplified Chinese characters. As a result educational institutions should make sure that students are familiar with both types of script. Almost all universities begin teaching Chinese by introducing first the traditional Chinese ideographic characters, following up afterwards with the simplified Chinese ideographic characters. Furthermore, learning the transcription system should involve competence in both the Pinyin and the Zhuyin Fuhao systems. Currently most Chinese courses focus on the traditional Chinese ideographic characters and on the Pinyin transcription system, which prove less rigorous. Incidentally, language textbooks using the traditional writing systems along with the Pinyin system are not readily available. Consequently, there is a shortage of suitable textbooks.

2. Another very serious problem is scarcity of high-calibre teachers. In the early nineties, a number of universities wish to initiate a Chinese program but they simply could not fill up the teaching posts, let alone the post of the head of department. With regard to the department head post in particular, the Office of Universities Bureau has stipulated that the head of department's minimum academic qualifications should be at the level of a master's degree in the relevant academic discipline. The crux of the problem was the non-existence at that time of a master's program in Chinese at Thai universities. Besides, there were then as few as 10 people with master's degrees in Chinese from universities abroad. To solve this problem, Chulalongkorn University which enjoyed then the distinction of having the best qualified faculty as befitting a flagship institution, put forward proposals to initiate a master's degree program in Chinese. The plan was finally approved and the first batch of graduate students arrived in 1996. The program proves a 
success, with the support of visiting guest lecturers who are leading Chinese language experts from countries such as China, Hong Kong, and the USA. Of 22 recent graduates, 15 have taken up university teaching posts. Additionally, six master's degree students who are now writing their theses will take up their positions as university lecturers at various institutions upon the completion of their degree. There are also a larger number of master's degree holders from abroad. It can be said that these days the problem of Chinese language teacher shortage at university level is being alleviated. However, the problem of human resource inadequacy at educational institutions below university status has not been solved. At present most teachers in charge of programs leading to professional vocational school diplomas, as well as most secondary and primary school teachers have not had any formal schooling in Chinese, nor have they increased their knowledge of Chinese beyond primary level. The Ministry of Education is fully aware of this state of affairs and is keen to promote continuing professional development and training of Chinese language teachers. Under this promotion scheme, professional training courses have been organized for the benefit of schoolteachers free of charge. Indeed the Ministry of Education requested the Chinese Division at Chula to run such a training program for four groups of teachers, completely funded by the Ministry. Seventythree teachers from about twentyfive secondary schools nationwide participated in the training program. The duration of the program was 60 hours for each group. The training course focused on the grammar and pronunciation of Mandarin. Nevertheless, other areas were also covered, for instance teaching
Chinese as a foreign language and Chinese cultural studies. The experts who conducted the training program included visiting specialists from Beijing, Taiwan, and instructors from within the Division of Chinese at Chula.

The training program for teachers of Chinese under the auspices of the Ministry of Education has highlighted the serious pedagogical and personnel problems. Around $80 \%$ of schoolteachers of Chinese studied the language in elementary classes only. There are some who have had teaching experience in other subjects, and are now taking Chinese lessons with a view to becoming Chinese language teachers in the future, just because Chinese is now an exceedingly popular subject. It is clear that those secondary schoolteachers have hardly been taught the basic elements of Chinese grammar and phonetics. Nor have they been exposed to the academic discipline of Teaching Mandarin as a Foreign Language. Hence, they are at a loss to correct or explain student's mistakes. Moreover, their Chinese pronunciation is not exactly flawless, to put it mildly. This type of inadequacy is very difficult to reverse as those teachers have been used to non-standard pronunciation since childhood days.

The current problem facing secondary schools is one of shortage of teachers with a bachelor's degree in Chinese. Usually, upon graduation, holders of a bachelor's degree in Chinese head straight for work in the private sector where they can command higher compensation, often turning their noses up at teaching jobs in the process. The short training course funded by the Ministry of Education is just a strategy for dealing with long-standing problems 
on an ad hoc basic, leading to only a partial solution.

\section{Recommendations}

A shortage of high-ability teachers is a serious difficult calling for prompt action. As for higher education institutions, universities have quite successfully managed to cope, primarily recruiting holders of master's degree in Chinese and later providing them with scholarships for Ph.D. degree programs abroad. Altematively, universities sornetimes groom high-achieving undergraduates for teaching posts on the faculty that they will take up upon completion of their bachelor's degrees. The universities will encourage such recruits to continue their studies to master's degree and doctoral levels, so that they can fulfill their potential in the teaching profession.

As for educational institutions below university level, they should receive government support in the development of their academic staff. The government should support them by encouraging teachers to take a long study leave abroad for attaining academic qualifications (up to bachelor's level at least). Junior academic staff members in particular should be sent to China or Taiwan to improve their Chinese and/or to enroll in courses on Teaching and Learning Chinese as a Foreign Language. Concurrently, the government should aim to recruit experienced Chinese teachers from China and Taiwan and should forge collaborative links with the two countries. Such links could lead to Thailand playing host to visiting instructors with expertise in Chinese language teaching, who would be assigned to a variety of schools, at least one per each, to serve as supervisors and mentors to Thai Chinese language teachers.

To solve problems related to appropriate textbooks, the government should assign to a team of scholars the task of compiling quality textbooks for use at different academic levels. This is likely to be a long-term project. However, the solution to the immediate problem of textbook shortage at secondary level is through a vigorous search for highquality textbooks from China or Taiwan. Then the government should proceed through appropriate channels as regards copyright matters, so that the texts could be adapted and tailored to the needs of Thai students.

\section{References}

Chokkajitsumpun, Pranee. 1988. Chinese Literacy Maintanance and shift in Banhgkok: Individual and Family Cases. Ph.D. dissertation, University of Hawaii.

Coughlin, Richard J. 1960. Double Identity: The Chinese in Modern Thailand. Hong Kong: Hong Kong University Press.

Ministry of Education, Krom Wisamansuksa. 1975. "Roongrian-raat phuson phaasaa chin" (Private school for teaching Chinese). Ekkasaankaansuksa, Wisamansuksa 7, Bangkok.

Ministry of Education. 1999. Statistics of Private Schools 1998. Bureau of Private Education. Bangkok.

Ministry of University Affairs. 2000. Compendium of Fields of Study in Private Higher Education Institutions. Bureau of Private Higher Education. Bangkok.

Sachakul, Kanniga. 1984. Education as a Means for National Integration: 
Chinese language Teaching in Thailand

Historical and Comparative Study of Chinese and Muslim Assimilation in Thailand. Ph.D. dissertation, University of Michigan.

Skinner, W. 1962. Chinese Society in Thailand: An Analytical History. New York: Cornell University Press. 
Table 1: Chinese schools in 2003

\section{Appendix}

\begin{tabular}{|c|c|c|}
\hline Part of Thailand & Provinces & Number of Schools \\
\hline Central & $\begin{array}{l}\text { Bangkok } \\
\text { Kanchanaburi } \\
\text { Nakhon Pathom } \\
\text { Nonthaburi } \\
\text { Pathum Thani } \\
\text { Prachuap Khiri Khan } \\
\text { Phra Nakhon Si Ayutthaya } \\
\text { Phetchaburi } \\
\text { Ratchaburi } \\
\text { Samut Prakan } \\
\text { Samut Songkhram } \\
\text { Samut Sakhon } \\
\text { Saraburi } \\
\text { Suphan Buri }\end{array}$ & $\begin{array}{c}26 \\
1 \\
4 \\
1 \\
5 \\
2 \\
3 \\
1 \\
3 \\
1 \\
1 \\
1 \\
2 \\
2 \\
\end{array}$ \\
\hline Eastern & $\begin{array}{l}\text { Chanthaburi } \\
\text { Chachoengsao } \\
\text { Chon Buri } \\
\text { Nakhon Nayok } \\
\text { Prachin Buri } \\
\text { Rayong }\end{array}$ & $\begin{array}{l}1 \\
3 \\
5 \\
1 \\
2 \\
1\end{array}$ \\
\hline Northeastern & $\begin{array}{l}\text { Khon Kaen } \\
\text { Nakhon Phanom } \\
\text { Nakhon Ratchasima } \\
\text { Buri Ram } \\
\text { Si Sa Ket } \\
\text { Surin } \\
\text { Nong Khai } \\
\text { Udon Thani } \\
\text { Ubon Ratchathani }\end{array}$ & $\begin{array}{l}2 \\
1 \\
4 \\
2 \\
1 \\
3 \\
1 \\
1 \\
1 \\
\end{array}$ \\
\hline Northern & $\begin{array}{l}\text { Chiang Rai } \\
\text { Chiang Mai } \\
\text { Tak } \\
\text { Nakhon Sawan } \\
\text { Nan } \\
\text { Phichit } \\
\text { Phitsanulok } \\
\text { Phetchabun } \\
\text { Phrae } \\
\text { Lampang } \\
\text { Sukhothai }\end{array}$ & $\begin{array}{l}1 \\
1 \\
2 \\
3 \\
1 \\
2 \\
1 \\
1 \\
1 \\
1 \\
4\end{array}$ \\
\hline Southern & $\begin{array}{l}\text { Chumphon } \\
\text { Trang }\end{array}$ & $\begin{array}{l}1 \\
2\end{array}$ \\
\hline
\end{tabular}




\begin{tabular}{|l|l|c|}
\hline & Nakhon Si Thammarat & 1 \\
& Narathiwat & 2 \\
& Pattani & 2 \\
& Phatthalung & 1 \\
& Phuket & 1 \\
& Yala & 2 \\
& Ranong & 1 \\
& Songkhla & 3 \\
& Satun & 1 \\
& Surat Thani & 1 \\
\hline
\end{tabular}

Table 2: Secondary schools offering Chinese

\begin{tabular}{|l|c|}
\hline \multicolumn{1}{|c|}{ Province } & School \\
\hline Bangkok & $\begin{array}{c}\text { Sitabutbamrung School } \\
\text { Phadungkitwitthaya School } \\
\text { Phattharaphakdi School }\end{array}$ \\
\hline Nakhon Pathom & Jian Hua School \\
\hline Chon Buri & Wutthiwitthaya School \\
\hline Nakhon Ratchasima & Jing De School \\
\hline Tak & Ratwitthaya School \\
\hline Lampang & Prachawit School \\
\hline Nakhon Si Thammarat & Charoenwit School \\
\hline Phuket & Prasatwit School \\
\hline Yala & Zhonghua Foundation School \\
\hline Songkhla & Srinakhon School \\
\hline
\end{tabular}

Table 3: Institutes at university level offering Chinese

\begin{tabular}{|l|l|}
\hline Programs & \multicolumn{1}{|c|}{ University } \\
\hline Chinese major & Chulalongkorn University \\
& Prince of Songkhla University Pattani Campus \\
& Thammasat University \\
& Silpakorn University \\
& Srinakharinwirot University \\
& Burapha University \\
& Naresuan University \\
& University of the Thai Chamber of Commerce \\
& Rangsit University \\
& Chiang Mai University \\
& Maha Sarakham University \\
& Chiang Mai Rajabhat University \\
& Lampang Rajabhat University \\
\hline
\end{tabular}




\begin{tabular}{|c|l|}
\hline & Suan Sunandha Rajabhat University \\
& Ramkhamhaeng University \\
& Krirk University \\
\hline Business Chinese as major & Assumption University \\
& Dhurakijpundit University \\
& Huachiew Chalermprakiet University \\
& Mae Fah Luang University \\
\hline Chinese as minor & Kasetsart University \\
& Bangkok University \\
& Yonok University \\
\hline Chinese as electives & Mahidol University \\
& Walailak University \\
& Siam University \\
& Thaksin University \\
& Payap University \\
& Pibulsongkram Rajabhat University \\
& Suan Dusit Rajabhat University \\
& Chiang Rai Rajabhat University \\
& Ratchaphat Bansomdej University \\
\hline
\end{tabular}

